\title{
The crab Neohelice (=Chasmagnathus) granulata: an emergent animal model from emergent countries
}

\author{
Eduardo D. Spivak
}

Received: 2 November 2009/Revised: 15 March 2010/Accepted: 17 March 2010/Published online: 4 April 2010

(C) Springer-Verlag and AWI 2010

\begin{abstract}
Neohelice granulata (previously known as Chasmagnathus granulata and C. granulatus) is a burrowing semiterrestrial crab found in the intertidal zone of estuaries, salt marshes and mangroves of the South-western Atlantic Ocean. Beginning in the late 1989s, an explosion of publications appeared in international journals dealing with its ecology, physiology, toxicology and behavior. A bibliometric analysis using the Scopus database allowed detecting 309 papers that deal with this species during the period 1986-2009. The number of papers per year increased continuously, reaching a mean annual value of 22.6 during the last 5 years; a great majority of them were authored by researchers from Argentina and Brazil. Neohelice granulata has become now one of the most studied crab species, after Carcinus maenas, Callinectes sapidus, Scylla serrata and Cancer pagurus and C. magister, and it can be considered as an emergent animal model for biochemical, physiological and ecological research.
\end{abstract}

Keywords Emergent animal model $\cdot \mathrm{Crab} \cdot$ Argentina Brasil

The intense growth of biological knowledge that took place during the last century was achieved with the help of a reduced number of species whose properties allow them to be suitable for experimental procedures: the biological

Communicated by H.-D. Franke.

E. D. Spivak $(\square)$

Universidad de Mar del Plata and Consejo Nacional

de Investigaciones Científicas y Técnicas,

Casilla de Correo 1245, 7600 Mar del Plata, Argentina

e-mail: espivak@mdp.edu.ar models (Fields and Johnston 2009). The progress in cellular physiology and biochemistry was based on the study of "simple organisms" as the bacterium Escherichia coli and the yeast Saccharomyces cerevisiae in laboratories all over the world; some mammals were the "complex" counterpart: rabbits, rats and especially mice (Mus musculus). On the other hand, few other animal models allowed the development of, for example, genetics (the fruit fly Drosophila melanogaster and the round worm Caenorhabdites elegans), embryology (the species mentioned above plus the frog Xenopus laevis, the sea urchin Strongylocentrotus purpuratus, the zebrafish Danio rerio, and chicken), or neurobiology (the squid Loligo pealei, the crayfish Procambarus clarkia and the sea hare Aplysia californica). The success reached by several Nobel Prize laureates is partly due to the right choice of one of these models.

The number and variety of models is increasing and new species that are useful to study more specific issues are incorporated to the growing list of the so-called emergent models. For example, the Cold Spring Harbor (CSH) Protocols, an interdisciplinary journal that provides a source of research methods in basic biology, includes 32 emergent animal models; among them there are several invertebrates from different phyla (Porifera, Cnidaria, Ctenophora, Annelida, Mollusca), 9 arthropods (mainly insects) and 15 chordates (http://cshprotocols.cshlp.org/emo/). Few other emergent animal models are not included there (e.g., the hydrozoans Podocoryne carnea and the "immortal" Turritopsis dohrnii).

The whole group of Crustacea (crabs, shrimp, prawns, barnacles, woodlice and an incredible variety of forms, mainly_but not only-aquatic) is underrepresented as emergent models and only the amphipod Parahyale hawaiensis is included in the CSH Protocols. However, an 
extensive research activity has been carried in several crabs, as the European green crab Carcinus maenas and the edible blue crab Callinectes sapidus (e.g., Kennedy and Cronin 2007); these and several other crab species are usual models for the study of behavior and ecological relationships that are outside the scope of the CSH Protocols. The aim of this paper is to describe the rise of a new emergent animal model: the South-western Atlantic burrowing crab Neohelice granulata.

\section{Natural history and geographic distribution}

The burrowing and semiterrestrial crab Neohelice granulata (previously known as Chasmagnathus granulata and C. granulatus) is a key species in South American salt marshes, mudflats and estuaries, ranging from San José Gulf, northern Patagonia, Argentina $\left(42^{\circ} 25^{\prime} \mathrm{S} ; 64^{\circ} 36^{\prime} \mathrm{W}\right)$, through Uruguay, to Lagoa Araruama, Rio de Janeiro, Brazil $\left(22^{\circ} 57^{\prime} \mathrm{S} ; 42^{\circ} 50^{\prime} \mathrm{W}\right)$. The geographical distribution of this crab includes the entire Warm Temperate Western Atlantic Province (Spalding et al. 2007), known also as the Nor-Patagónica + Paulista Provinces and Argentine Province by local authors (Palacio 1982 and Boschi 2000, respectively) and the northern part of the northern ecoregion of the Magellan Province: the North Patagonian Gulfs (sensu Spalding et al. 2007). Through this $20^{\circ}$ latitudinal gradient, $N$. granulata habitats vary from mangroves in the north to the saltmarshes of Northern Patagonia, in the south.

Dense populations are found over this area, reaching values as high as $>100$ individuals $/ \mathrm{m}^{2}$. Juvenile and adult $N$. granulata are confined geographically to the intertidal of estuaries and bays, separated by tens or thousands kilometers; indirect evidences indicate that $N$. granulata planktonic larvae (4 or 5 zoeae, one megalopa; Boschi et al. 1967; Pestana and Ostrensky 1995) are exported from some parental habitats (Anger et al. 1994) although they were only found in nearshore marine waters (Bas et al. 2009).

\section{The discovery of Neohelice granulata: travelling naturalists of the XIX century}

During the XIX century, the taxonomic status and geographical distribution of $N$. granulata were established on the basis of collections made by European and North American expeditions. The first scientific report was probably a note by Alcide d'Orbigny, who took part in a seven-year expedition (1826-1834) to South America; it is included in the handwritten catalog of his collections (Guinot and Cleva 2002). The collection sites mentioned thereof were: Montevideo ( $\left.34^{\circ} 54^{\prime} \mathrm{S}\right)$, "Plata" (probably Samborombón Bay, from $35^{\circ} 26^{\prime}$ to $36^{\circ} 18^{\prime} \mathrm{S}$ ), "Baie Blanche" (Bahía Blanca, from $39^{\circ} 26^{\prime}$ to $39^{\circ} 00^{\prime} \mathrm{S}$ ), "Baie St. Blas" (San Blas Bay, $40^{\circ} 33^{\prime} \mathrm{S}$ ) and "Rio Negro" (probably the mouth of Negro river, $41^{\circ} 03^{\prime} \mathrm{S}$ ). d'Orbigny (1835-1847) also described the habitat of this species in Bahía Blanca and mentioned that the name given by the inhabitants of this region to the large muddy tidal flats covered by $N$. granulata burrows was "cangrejales" (from the Spanish "cangrejo" = crab). Nicely, a literary description of a "cangrejal", the crabs, and their burrows appeared in a famous novel that tells the adventures of a gaucho in the Argentine pampa (Don Segundo Sombra; Güiraldes 1926); this description agreed very much with D'Orbigny notes (1835-1947), in particular when it tells the story of horses that sunk in the mud and got stuck up to their bellies.

The species was then formally described, illustrated and named Chasmagnathus granulatus by Dana $(1851,1852)$ on the basis of specimens collected on "marshes of Lake Peteninga, near Rio Janeiro, Brazil" by the United States Exploring Expedition (1838-1842). The description was then reproduced by Milne Edwards (1853) in the "Mémoire sur la famille des Ocypodiens".

Later, the following expeditions or individuals collected specimens at Rio de Janeiro, Florianópolis and Rio Grande (Brasil), Maldonado and Montevideo (Uruguay) and Puerto San Antonio and San Matías Bay (Argentina): Novara (1857), Capt. Harrington (1859), Berliner Akademie (1863-1866), Thayer (1865-1866), Hassler (1872), H.M.S. "Alert" (1878), Albatross (1885-1887) and G. Schneider (1888). Crabs were described or identified by Heller (1865), Smith (1869), von Martens (1869), Kingsley (1880), Miers (1881), Rathbun (1898) and Ortmann (1894) and also named as Helice cranulata (sic), Helice granulata and Chasmognathus (sic) granulatus.

\section{Systematics}

Rathbun (1918) redescribed the species under the name Chasmagnathus granulata; in spite of the disagreement in gender between the generic and the specific names, the species remained mentioned as $C$. granulata (e.g., Boschi 1964) during most of the XX century. However, C. granulatus has been still used by some authors (e.g., Lozada et al. 1988). Sakai, Türkay and Yang (2006) revised and reclassified all species formerly attributed to the genera Helice and Chasmagnathus (the "Helice/Chasmagnathus complex"), redefined both genera that are now restricted for species from east Asian seas, and introduced new genera for the species from South America (Neohelice), New Zealand (Austrohelice) and the subtropical and 
tropical Indo-Pacific (Pseudohelice). Accordingly, the species is now named Neohelice granulata (Dana 1851). It belongs to the superfamily Grapsoidea, family Varunidae (Schubart et al. 2002).

\section{Developing a model}

During the first three quarters of the XX century, $N$. granulata was mentioned in several disperse studies that appeared in Brazilian and Argentine journals; for example: Moreira (1901), Boschi (1964), Boschi et al. (1967) and Mañé Garzón et al. (1974). The first two contributions were, in fact, studies on the crab fauna of Brazil (Moreira 1901) and Buenos Aires province (Argentina, Boschi 1964), but the latter included the first ecological information on the relationships of this species with the other two intertidal crabs that inhabit the western coasts of the Rio de la Plata estuary (Uca uruguayensis and Cyrtograpsus angulatus). The third paper includes the first description of the larval development from laboratory cultures, and the fourth is the first physiological study (osmoregulation) of this crab, carried on in a Uruguayan population. A burst of publications in international journals dealing with ecology, physiology and behavior of $N$. granulata took place since the late 1980 s. In fact, Sakai et al. (2006) cited 124 "morphological, taxonomic, distributional and ecological papers, which contribute to the understanding of the life cycle and relationships of the species", dated from 1851 to 2004. Although in the remarks that follows the diagnosis and distribution of $N$. granulata these authors stated that "it has received some attention from physiologists and ethologists" (p. 64), they had previously written that there "has been so much physiological and biochemical work that even mere citation would have inflated the paper to an unacceptable extent" (p. 2).

\section{A bibliometric analysis}

A bibliometric analysis using the Scopus database allowed detecting 312 papers that included the words Chasmagnathus or Neohelice in the title, abstract and/or keywords during the period 1986-2009, in all the subject areas; 3 of them dealed with $C$. convexus; the remaining 309 dealed with $N$. granulata (Fig. 1). This database involves not only international but also some regional journals as well (e.g., Brazilian Archives of Biology and Technology, Brazilian Journal of Biology and Iheringia); the few papers about Chasmagnathus/Neohelice that appeared in other regional journals not considered by Scopus (e.g., Investigaciones Marinas, Valparaíso) were not considered in the analysis.
The number of authors involved in this production, after deleting duplications due to different ways to write the names, was 367 . These researchers belong to 15 countries: Argentina (191), Brazil (122), Germany (12), USA (12), Italy (9), Canada (4), France (4), Spain (3), Chile (2), United Kingdom (2), Uruguay (2), China (1), Finland (1), Japan (1) and Sweden (1). Most of the Latin-American authors are affiliated to universities of cities from southern Brazil (mainly Porto Alegre and Rio Grande), Uruguay (Montevideo) and Argentina (mainly Buenos Aires and Mar del Plata); the contributions of scientists from other countries usually arise as a consequence of cooperative bilateral projects (e.g., with the marine biological institute of Helgoland (Germany).

Neohelice granulata was the sixth most studied crab species, after Carcinus maenas, Callinectes sapidus, Scylla serrata, Cancer pagurus and C. magister and before Eriocheir sinensis, Uca pugilator and Chionoecetes opilio (Fig. 1). The number of papers per year increased continuously, reaching a mean annual value of 22.6 during the last 5 years (Fig. 2).

These papers were roughly classified in disciplines, on the basis of the title, as follows: ecology, morphology, development (embryonic and larval biology) and life history studies, 33.5\%; physiology, other than neural, and biochemistry, 29.4\%; neurophysiology and neurobiology, $24.0 \%$; and toxicology, $13.1 \%$. The accumulative number of papers during the period 1986-2008 has a similar trend among disciplines (Fig. 3).

Most of the projects developed using $N$. granulata as a model for biological research at individual or populational levels were related with the evolutionary transitions from marine to estuarine environments and with two biological characteristics of the species: euryhalinity and semiterrestriality. The following are examples of such projects: embryonic, larval and adult structural, biochemical and physiological adaptations to reduced or changing salinities; developmental plasticity and carry-over effects (e.g., effects of the salinity or nutrition experienced at one developmental stage on the following stages, see a review by Giménez 2006); strategies of larval export; cues for settlement; post-settlement patterns and processes in estuarine habitats; the effects of season, diet, anoxia and osmotic stress on carbohydrate and lipid metabolism; and the effects of pollutants, particularly heavy metals and pesticides on different phases of the life cycle (see Bianchini et al. 2008; Pellegrino et al. 2008; Anger et al. 2008 and the references herein).

On the other hand, Neohelice granulata has proved to be an excellent model to investigate the neurobiology of memory (Maldonado 2002; Tomsic et al. 2009; Fathala et al. 2010a, b) on the basis of the "context-signal learning paradigm: the repeated presentation of a danger stimulus 
Fig. 1 Number of papers published between 1986 and 2009 and dealing with different crab species that were listed in the Scopus Database. The search was based on the appearance of each specific name in the title, abstract and/or keywords in all the subject areas except in Neohelice granulata. In the latter, the search was based on both generic names Chasmagnathus and Neohelice (*) and the few papers dealing with $C$. convexus were eliminated

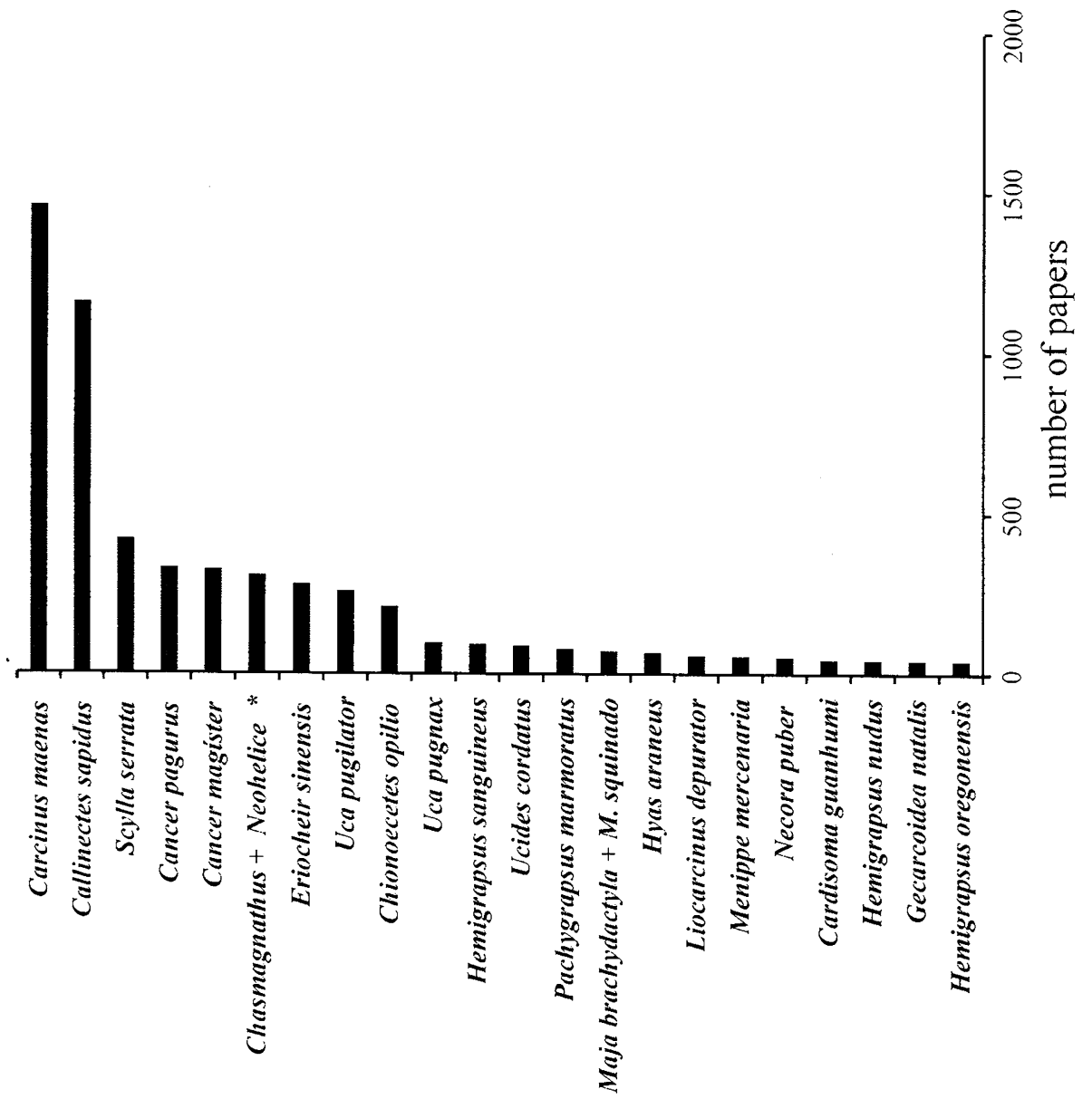

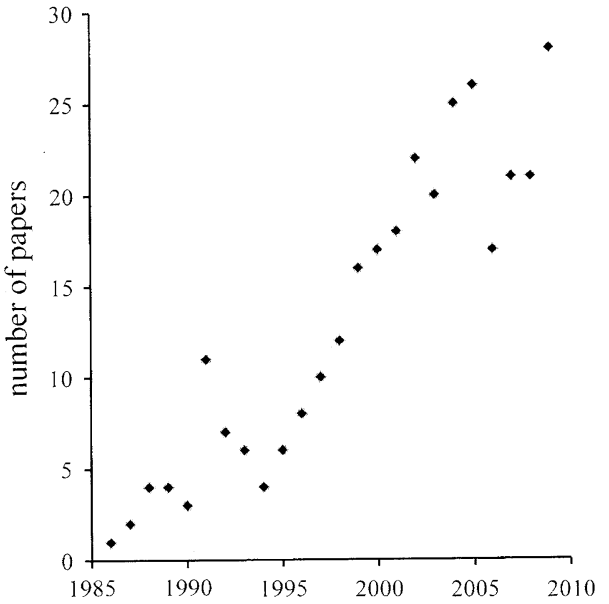

Fig. 2 Number of papers published between 1986 and 2009 and dealing with Neohelice granulata that were listed in the Scopus Database. The search was based on the appearance of the words Chasmagnathus or Neohelice in the title, abstract and/or keywords and the few papers dealing with $C$. convexus were eliminated

provokes the fading of the escape response that was initially elicited" (http://www.fbmc.fcen.uba.ar/LNM/). The extensive behavioral and physiological studies carried out in Dr. Héctor Maldonado's laboratory included the signal transduction pathways and gene expression mechanisms involved in the different phases of memory, the role of angiotensin II in response to an environmental water shortage, the neural control of visually elicited escape behaviors and the changes of these behaviors by learning and memory (the website mentioned earlier includes a list of publications).

Finally, the role of this crab as an "ecological ecosystem engineer" in saltmarshes and estuaries was intensely investigated, discovering that the burrowing activity and subsequent sediment turnover greatly impacts sediment chemistry; enhances both soil drainage and aeration; traps organo-chlorine pesticides; increases $S$. densiflora productivity; affects the benthic community (e.g., the activity of the crabs Cyrtograpsus angulatus and Uca urugayensis, the razor clam Tagelus plebeius and the polychaete Laeonereis acuta among other invertebrate species), the distribution and abundance of juvenile fishes, the habitat use and migration of shorebirds and even the foraging of rodents (e.g., Alberti et al. 2008; Botto et al. 2008; Canepuccia et al. 2008; Escapa et al. 2008; Fanjul et al. 2008; Daleo and Iribarne 2009). In fact, most of the publications of Dr. Oscar Iribarne laboratory (Mar del Plata, Argentina) included the words "effects of ..." in their titles. A 


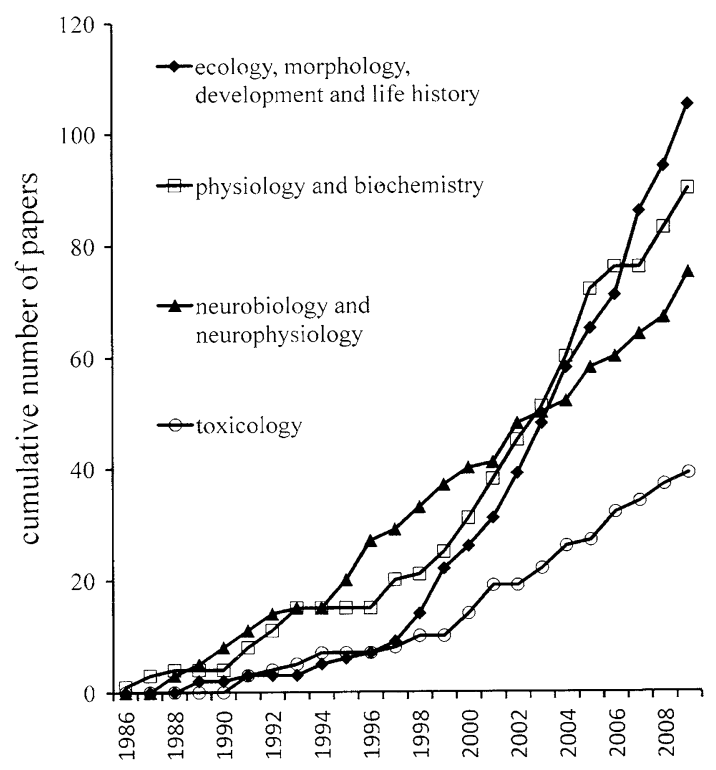

Fig. 3 Accumulative number of papers published during the period 1986-2009 and dealing with Neohelice granulata that were listed in the Scopus Database. These papers were grouped in 4 categories: (1) ecology, morphology, development and life history; (2) physiology, other than neural, and biochemistry; (3) neurobiology and neurophysiology; and (4) toxicology. The search was based on the appearance of the words Chasmagnathus or Neohelice in the title, abstract and/or keywords and the few papers dealing with $C$. convexus were eliminated

complete list of publications from this team can be found in the web site http://www.ecologia.mdp.edu.ar/english/ publications/papers.htm.

As Fields and Johnston (2009) pointed out, "to focus on just a few experimentally tractable organisms" allowed biologists to understand many of the fundamental properties of life but tended to restrict their vision. Following these authors, the incorporation of emerging animal models may be the way to learn about many particular (e.g., how to cope with extreme environments) or general (e.g., how to organize complex communities) biological problems. What it is remarkable about Neohelice granulata as a research model is not only its tractability but the fact that it is being used simultaneously for molecular, physiological and ecological studies.

Acknowledgments Thanks are due to Richard Greene from the Natural History Library, Smithsonian Institution, Washington, USA and Wolfgang Brunnbauer from the Zoologische Hauptbibliothek, Naturhistorisches Museum in Wien, for their help in the access to old studies, to my colleagues and friends Claudia Bas and Tomás Luppi for their continuous commitment to $N$. granulata research, and to Klaus Anger (Helgoland Biological Institution), Oscar Iribarne (Mar del Plata University) and Daniel Tomsic (Buenos Aires University) for their useful comments on an early version of this paper.

\section{References}

Alberti J, Escapa M, Iribarne OO, Silliman B, Bertness M (2008) Crab herbivory regulates plant facilitative and competitive processes in Argentinean marshes. Ecology 89:155-164

Anger K, Spivak E, Bas C, Ismael D, Luppi T (1994) Hatching rhythms and dispersion of decapod crustacean larvae in a brackish coastal lagoon in Argentina. Helgol Meeresunters 48:445-466

Anger K, Spivak E, Luppi T, Bas C, Ismael D (2008) Larval salinity tolerance of the South American salt-marsh crab, Neohelice (Chasmagnathus) granulata: physiological constraints to estuarine retention, export and reimmigration. Helgol Mar Res 62:93102

Bas C, Luppi T, Spivak E, Schejter L (2009) Larval dispersion of the estuarine crab Neohelice granulata in coastal marine waters of the Southwest Atlantic. Estuar Coast Shelf Sci 83:569-576

Bianchini A, Lauer MM, Nery LEM, Colares EP, Monserrat JM, dos Santos EA (2008) Biochemical and physiological adaptations in the estuarine crab Neohelice granulata during salinity acclimation. Comp Biochem Physiol A Mol Integr Physiol 151:423-436

Boschi EE (1964) Los crustáceos decápodos Brachyura del litoral bonaerense (R.Argentina). Bol Inst Biol Mar, Mar del Plata (Argentina) 6:1-99

Boschi EE (2000) Species of decapod crustaceans and their distribution in the American marine zoogeographic provinces. Rev Invest Desarro Pesq 13:7-136

Boschi EE, Scelzo MA, Goldstein B (1967) Desarrollo larval de dos especies de crustáceos decápodos en el laboratorio: Pachycheles haigae Rodrigues da Costa (Porcellanidae) y Chasmagnathus granulata Dana (Grapsidae). Bol Inst Biol Mar, Mar del Plata 12:1-46

Botto F, Méndez Casariego A, Valiñas M, Iribarne OO (2008) Spatial heterogeneity created by burrowing crabs affects human impact on migratory shorebirds. Estuaries Coasts 31:134-143

Canepuccia A, Fanjul MS, Fanjul E, Botto F, Iribarne OO (2008) The intertidal burrowing crab Neohelice (=Chasmagnathus) granulata positively affect rodents in south western Atlantic salt marshes. Estuaries Coasts 31:920-930

d'Orbigny A (1835-1847) Voyage dans l'Amérique méridionale (le Brésil, la République Orientale de l'Uruguay, la République Argentine, la Patagonie, la République du Chili, la République de Bolivia, la République du Pèrou) exécuté pendant les années $1826,1827,1828,1829,1830,1831,1832$ et 1833. PitoisLevrault, Paris

Daleo P, Iribarne OO (2009) The burrowing crab Neohelice granulata affects the root strategies of the cordgrass Spartina densiflora in SW Atlantic salt marshes. J Exp Mar Biol Ecol 373:66-71

Dana JD (1851) Crustacea Grapsoidea, (Cyclometopa, Edwardsii): Conspectus Crustacearum quae in Orbis Terrarum circumnavigatione, Carolo Wilkes e classe Reipublicae Foederatae Duce, lexit et descriptsit J.D. Dana. Proc Acad Nat Sci Phila 5:247-254 (printed in 1852)

Dana JD (1852) Crustacea. US Exploring Expedition. During the years 1838, 1839, 1840, 1841, 1842. Under the command of Charles Wilkes, U.S.N. C. Sherman. Philadelphia

Escapa M, Perillo GME, Iribarne OO (2008) Sediment dynamics modulated by burrowing crab activities in contrasting SW Atlantic intertidal habitats. Estuar Coast Shelf Sci 80:365-373

Fanjul E, Grela MA, Canepuccia A, Iribarne OO (2008) The Southwest Atlantic intertidal burrowing crab Neohelice granulata modifies nutrient loads of phreatic waters entering coastal areas. Estuar Coast Shelf Sci 79:300-3006 
Fathala MV, Iribarren L, Kunert MC, Maldonado H (2010a) A field model of learning: 1 . Short-term memory in the crab Chasmagnathus granulatus. J Comp Physiol A196:61-75

Fathala MV, Kunert MC, Maldonado H (2010b) A field model of learning: 2. Long-term memory in the crab Chasmagnathus granulatus. J Comp Physiol A 196:77-84

Fields S, Johnston M (2009) Whither model organism research? Science 307:1885-1886

Giménez L (2006) Phenotypic links in complex life cycles: conclusions from studies with decapod crustaceans. Integr Compar Biol 46:615-622

Guinot D, Cleva R (2002) Les Crustacés récoltés par dOrbigny en Amérique du Sud et déposés au Muséum national d'histoire naturelle, Paris. Comptes Rendues Palevol 1:499-515

Güiraldes R (1926) Don Segundo Sombra, Proa Editores, Buenos Aires. (English translation by P. Owen Steiner and G. Kirkpatrick: Pittsburgh Editions of Latin American Literature)

Heller C (1865) Crustaceen. In: Reise der österreichischen Fregatte Novara um die Erde in den Jahren 1857, 1858, 1859 unter den Befehlen des Commodore B.von Wüllerstorf- Urbair. Zoologischer Theil. Zweiter Band. III Abteilung. Kaiserliche Akademie der Wissenschaften, Wien

Kennedy VS, Cronin LE (eds) (2007) The blue crab Callinectes sapidus. Maryland Sea Grant Publication, Maryland

Kingsley JS (1880) Carcinological Notes no 4. Synopsis of the grapsidae. Proc Acad Nat Sci Philadelphia 1880:187-332 (printed in 1881)

Lozada M, Romano A, Maldonado H (1988) Effect of morphine and naloxone on a defensive response of the crab Chasmagnathus granulatus. Pharmacol Biochem Behav 30:635-640

Maldonado H (2002) Crustaceans as models to investigate memory illustrated by extensive behavioral and physiological studies in Chasmagnathus. In: Wiese $\mathrm{K}$ (ed) The crustacean nervous system. Springer, Berlin

Mañé Garzón F, Dei-Cas E, Holcman-Spector B, Leymonié J (1974) Estudios sobre la biología del cangrejo de estuario Chasmagnathus granulata. Physis A 33:163-171

Miers EJ (1881) An account of the zoological collections made during the survey of H.M.S. "Alert" in the Straits of Magellan and on the coasts of Patagonia. 6. Crustacea. Proc Zool Soc London 1881:61-79

Milne Edwards M (1853) Mémoire sur la famille des Ocypodiens. In: Milne Edwards M (ed) Annales des Sciences Naturelles, 3e. Serie. Zoologie 20:163-320. Masson, Paris

Moreira C (1901) Contribuiçoes para o conhecimento da fauna brazileira. Crustáceos do Brazil. Arch Mus Nac Rio de Janeiro $11: 1-151$
Ortmann AE (1894) Abtheilung: Brachyura (Brachyura Genuina Boas), III. Unterabtheillung: Cancroidea, 2. Section: Cancrinea, 2. Gruppe: Catometopa, Die Decapoden-Krebse des Strassburger Museums, mit besonderer Berücksichtigung der von Herrn Dr. Doderlein bei Japan und bei den Liu-Kiu-Inseln gesammelten und zur Zeit im Strassburger Museum aufbewahrten Formen, VIII. Theil. Zoologische Jahrbücher. Abteilung für Systematik, Geographie und Biologie der Tiere 7:683-772

Palacio FJ (1982) Revisión zoogeografica marina del sur del Brasil. Bol Inst Oceanogr São Paulo 31:69-92

Pellegrino R, Kucharski LC, Da Silva RSM (2008) Effect of fasting and refeeding on gluconeogenesis and glyconeogenesis in the muscle of the crab Chasmagnathus granulatus previously fed a protein- or carbohydrate-rich diet. J Exp Mar Biol Ecol 358:144-150

Pestana D, Ostrensky A (1995) Occurrence of an alternative pathway in the larval development of the crab Chasmagnathus granulata Dana, 1851 under laboratory conditions. Hydrobiologia 306:33-40

Rathbun MJ (1898) The Brachyura collected by the US Fish Commission Steamer "Albatross" on the voyage from Norfolk, Virginia to San Francisco, California, 1877-1888. Proc US Nat Mus 21:567-616

Rathbun MJ (1918) The grapsoid crabs of America. Bull US Nat Mus 97:1-461

Sakai K, Türkay M, Yang SL (2006) Revision of the Helicel Chasmagnathus complex (Crustacea: Decapoda: Brachyura). Abh Senckenberg Naturforsch Ges 565:1-76

Schubart CD, Cuesta JA, Felder DL (2002) Glyptograpsidae, a new brachyuran family from Central America: larval and adult morphology, and a molecular phylogeny of the Grapsoidea. J Crust Biol 22:28-44

Smith SI (1869) Notes of the Crustacea collected by Prof. C. F. Hartt on the coast of Brazil in 1867. Trans Conn Acad Arts Sci 2:1-41 (printed 1871-1873)

Spalding MD, Fox HE, Allen GR, Davidson N, Ferdaña ZA, Finlayson M, Halpern BS, Jorge MA, Lombana A, Lourie SA, Martin KD, Mcmanus E, Molnar J, Recchia CA, Robertson J (2007) Marine ecoregions of the world: a bioregionalization of coastal and shelf areas. Bioscience 57:573-583

Tomsic D, Beron de Astrada M, Sztarker J, Maldonado H (2009) Behavioral and Neuronal attributes of short- and long-term habituation in the crab Chasmagnathus. Neurobiol Learn Mem 92:176-182

von Martens E (1869) Südbrasilianische Süss-und BrackwwasserCrustaceen nach den Sammlungen des Dr. Reinh. Hensel. Arch Naturges 35:1-37 